zinc sulphate the author titrates the solution at about $100^{\circ}$ with the permanganate solution (of which a portion was reduced at the outset) until a pink color is obtained which persists even after the solution is boiled. The volume of permanganate solution required was in every case almost exactly two-thirds that of the permanganate solution reduced. This is obviously in accord with the ratio $3 \mathrm{MnCl}_{2}: 2 \mathrm{KMnO}_{4}$. The author recommends for actual work a procedure somewhat as follows: A sample of manganiferous iron ore (for example) is dissolved in hydrochloric acid; the filtered solution, moderately acid, is diluted to $500 \mathrm{cc}$. Two samples of roo cc. each are taken from this solution. To one of these samples is added the manganese chloride obtained by reduction of a measured volume of the permanganate solution with hydrochloric acid. After the iron has been removed from both samples by the addition of zinc oxide, the solutions are titrated with permanganate. From the difference the strength of the permanganate solution may be calculated, while from the lower result may be obtained the percentage of manganese in the sample.

The report upon this question contains also an article by $\mathrm{G}$. Chesneau which has been published elsewhere (Annales des Mines, Feb. (1906)). This piece of work contains some experimental evidence corroborating the conclusions of de Koninck.

Sub-committee XI. Question I4. Methods of Analyzing Materials Containing Tartaric Acid. (Pages 4I9-42I.)-For the determination of bitartrates it is proposed to abandon the method of direct titration without filtration. The approved method is briefly as follows: In a 500 cc. flask is placed 2.35 grams of the fine material, with $400 \mathrm{cc}$. of distilled water. The liquid is boiled for five minutes. Water is added, and the liquid is cooled, shaken, and is filtered upon a folded filter-paper. Of the filtrate $250 \mathrm{cc}$. are boiled in a porcelain dish, and titrated (neutral litmus-paper as indicator) with $\mathrm{N} / 4$ potash that has been standardized under the same conditions with a pure bitartrate. For the analysis of total tartaric acid the method of Goldenberg-Geromont (Z. anal. Ch. 37, 312 (1898)) is usually employed. This method has been studied in detail by the committee. A brief statement is also made concerning the correction to be introduced for the volume of solid material-a subject to be considered in greater detail in a future report.

\title{
RECENT WORK IN AGRICULTURAL CHEMISTRY.
}

\author{
Received June 18 , I906.
}

FERTILIZERS BY F. P. VEITCH.

As usual, numerous experiments have been made for the purpose of determining the relative value of different materials for supplying the essential elements, phosphoric acid, nitrogen and potash. 
Only those which are deemed most important need be mentioned here. Haselhoff (Landw. Jahrb. 34, 616-64I (I905)) has conducted a number of experiments to show the value of differently prepared and different mixtures of Thomas slag. Kuhnert (Mitt. deut. landw. Ges. 20, 334 (1905)) has found slag to give better results during the first year than crude ground phosphate. Clausen $(J$. landw. 53, 2I3-228 (1905)) has investigated by pot experiments the effect of phosphoric acid on oat plants grown on black peaty sand and has found the total yield to regularly increase while the relative yield of grain was decreased.

In an investigation of the influence of phosphoric acid on wines from grapes, Zacharewicz (Prog. agr. vit. (Ed. L' Est) 25, 459462 (I904)) finds that phosphoric acid may be accumulated in part in the fruit and contribute beneficially to the wine made from it. Montanari (Staz. sper. agr. ital. 38, 253-258 (I go5)), Quartaroli (Abs. in J. Chem. Soc. 88, ii, 549 (1905)), Pervinquiere (Rev. sci. 5, [4] 353-36I (1905)), and Katayama (Bull. Col. Agr. Tokyo Imp. Univ. 6, 353-356 (1905)) have contributed minor papers on phosphoric acid. Haselhoff (Landw. Jahrb. 34, 647-664, pl. I (I905)), in extended pot experiments with various potassium fertilizers on potatoes followed by wheat, finds that a partial subst tution of potassium chloride by sodium chloride resulted in a slight increase in yield of potatoes but a further increase of sodium chloride gave a decrease in yield. The smallest amount of potash was taken up by potatoes from the kainit. The author concludes that it appears probable that by the application of sodium chloride the potash of a soil is rendered soluble and more easily assimilated by plants.

By treating leucite with various salt solutions, and also with water, Monaca (Abs. in Centr. agr. Chem. 34, 7 I4 (I905)) succeeded in dissolving considerable potash from the finely ground material, such potash being considered assimilable plant food. Reitmair (Z. landw. Versuchsw. Oesterr. 8, 863-944 (I905)) reviews the work of other investigators regarding the conditions under which potash fertilization reduces the protein content of malted barley and concludes that the protein content is only reduced when the quantity of available potash in a soil is at a minimum and is especially reduced on the less fertile soils when a heavy application of nitrogen has been given. Stoklasa ( $Z$. landw. Versuchsw. Oesterr. 8, 957-982 (1905)) presents a reply to the conlcusions drawn by Reitmair on this subject. Vageler (Vrtljschr. bayer. landw. rat. Io, [2] (Ergänzungsh.), Sup. I, I25-133 (1905)) has examined I 43 cultivated Bavarian moor soils and finds that in spite of the fact that they are well supplied with potash they are much benefitted by a liberal application of potash fertilizers. Feilitzen (Svenska mosskulturför, tidskr, I9, 9I-100, pls. 4, Fig. I (I905)) finds that mangolds and potatoes grown on moor soils frequently show marked need of potash. Prianishnikov (Ber. 
deut. bot. Ges. 23, 8-17 (1905)), in reviewing experiments on the effect of ammonium salts on the assimilation of phosphoric acid, concludes that phosphates are rendered more soluble by these salts while sodium nitrate exerts no such effect. Bachmann (Fühling's landw. Ztg. 54, 219-223 (1905)) finds that calcium carbonate applied with sulphate of ammonia jucreases its action while the action of nitrate of soda is not materially affected by the calcium carbonate. Treboux (Ber. deut. bot. Ges. 22, 570-572 (I 904)) has studied the effect of various forms of nitrogen on chlorophyll-bearing plants and finds that nitrites, while generally available in alkaline soils, are poisonous in acid soils. Nitrates and nitrites were found to possess practically the same efficiency while ammonium salts were more available than either. Amines and amides are about equally valuable for the lower plants but amides are less assimilable for the higher chlorophyll-bearing plants. It is claimed that ammonium salts are most suited to the nitrogen nutrition of chlorophyll-bearing plants and that the intervention of nitrite and nitrate bacteria is not always necessary.

The value of calcium cyanamide or lime nitrogen as a nitrogen carrier has received a great deal of attention from European investigators, the following authors contributing to the literature on this subject: Haselhoff (Landw. Jahrb. 34, 597-616 (Igo5)); von Seelhorst and Müther (Abs. in J. Chem. Soc. 9o, ii, 46 (rgo6)); Immendorff and Thielebein (Fühling's landw. Ztg. 54, 787-795 (I905)); Ashby ( $J$. agr. sci. I, 358-360 (I905)); Grandeau ( $J$. agr. Prat., N. S., 10, 808 (1905)); von Feilitzen (Svenska Mosskulterför. Tidskr. 19, I00-I Io (1905)); Otto (Abs. in J. Chem. Soc. 88, ii, I96 (1905)); Söderbaum (Meddel. K. Landtbr. Akad. Exptäflt. (Stockholm), No. 85, 27), Löhnis (Abs. in Chem. Centr. I, I 73I); Wein (Chem. Ztg. 29, Io66 (1905)); Grandeau (J. agr. prat. N. S. II 8-IO (1906)). Without going into the details of these results, it may be said that in general the experiments have shown that the use of this material upon land on which crops are immediately to be planted, may prove decidedly injurious if large quantities of the material are applied but if the application be made some time before planting the crop, little, if any, injury results. As a nitrogen carrier this material promises to be a valuable addition to our fertilizer materials and to have a value about equal to ammonium sulphate, though this value will differ somewhat with the nature of the soil upon which the material is used.

The formation of nitric acid from the air has continued to occupy a prominent place in the experimental and technical fields and Birkeland and Eyde have devised a process that, according to Witt (J.Chem. Ind. 28, 699 (1905)), is exceedingly promising. The inveniors, instead of working with arcs of low amperage, utilize the action of a magnetic field on the arc, by placing powerful electromagnets vertically to the electrodes; the arc formed be- 
tween the electrodes is blown away, as it were, by the influence of the magnetic field and at once a new arc is formed which is also blown away. In practice, this formation and removal of the arc takes place several hundred times per second. With 30 kilowatts energy, dises of one metre diameter can be formed. The hollow electrodes are of copper and are cooled internally by water. A yield of 100 grams nitric acid per kilowatt hour is obtained at a cost of about I to 2 cents per kilo. The dilute acid is concentrated as much as possible by running the oxides into the solution which is then treated with lime water to form a calcium nitrite which is oxidized to nitrate by treatment with nitric acid. The solution is evaporated and fused, resulting in a basic nitrate which powders readily, and in contact with water, soil and carbon dioxide breaks down into calcium carbonate and nitrate. Schloesing (Compt. rend. I4I, 745 (1905)) finds calcium nitrate and nitrite as effective fertilizers as the sodium salts for maize. Bellenoux (Compt. rend. I40, II90 (I905)) finds calcium nitrate fully as valuable as sodium nitrate in the production of potatoes and sugar beets.

Other papers upon the value of various nitrogenous materials have been contributed by Lutz ( $B$ ull. soc. bot. france, 52, 159-162 (1905)); Haselhoff (Landw. Jahrb. 34, 642-646 (1905)); Aumann (Abs. in Centr. agr. Chem. 33, 852 (I904)); Björn-Anderson (Tidsskr. Landökonom. I60-I68 (1905)); Knecht (Chem. News, oI , 259-26I (I905)); Clausen (Deut. landw. Presse, 32, 6I I (I905)); Gerhardt (Chem. Ztg. 29, I94 (1905)); Schäfer (Fühling's landw. Ztg. 54, I 42-145 (I905)); Gerlach and Vogel (Abs. in Chem. Centr. I, I609 (I905)); Böhme (Illus. landw. Ztg. 24, IOOI, IOI I, and I023-1025 (I904)); Boullanger and Massol (Compt. rend. 140, 687-689 (1905)); Lutz (Compt. rend. 140, 380-382 (1905)); Weitz ("Der Chilisalpeter Düngemittel," Berlin: Paul Parey, (I905)); Müller and Spitzer (Ber. 38, 778-782 (1905)); Jamison ("Utilization of Nitrogen in Air by Plants," Report of the Agricultural Research Association of the $N$. E. Countries of Scotland (I9O5)) advances the startling doctrine "That plants generally absorb free nitrogen directly from air, and transform it into albumen, that the quantity absorbed and fixed varies according to the number and character of the special structures that perform such function, and to the presence of the conditions of growth necessary to secure development of such structures." It is further stated that neither fungi nor bacteria have the power of fixing free nitrogen but that this power is limited to chlorphyll-bearing plants, and that the seat of fixation is in certain structures of the leaf or stalk. The evidence upon which these conclusions are based is simply the presence of albuminous material in these above-mentioned structures. It is not likely that Jamison's conclusions will be accepted on the evidence submitted. Fisher (J. Landw. 53, 289-297 (1905)) in studying nitrogen-fixing bacteria 
has found that the activity of the organisms is greatly influenced by the character of the soil, particularly by its lime content and physical condition. In one soil where the several plots were differently manured only those to which lime has been applied contained Azotobacter. Löhnis (Centr. Bakt. I3, 706-7I5 (I904); I4, 582-604 (1905)) has studied the various nitrifying and denitrifying bacteria and concludes that because soil conditions are as a rule more favorable to nitrification than denitrification, the latter is inconsiderable in well aerated soils. Keutner ( $W$ iss. Meeresunters, abt. Keil 8) finds nitrogen-fixing bacteria widely distributed in sea water and in many fresh waters. $A$. chroococcum has the power to fix nitrogen in an 8 per cent. solution of sodium chloride.

The use of lime as an adjunct in agricultural practice is a subject receiving a great deal of attention, and Suzuki (Bull. Col. Agr. Tokyo Imp. Univ. 6, 347-35 I (I905)) finds that calcium carbonate decidedly depresses the assimilability of phosphoric acid by rice while calcium sulphate has no such effect. Powdered magnesite also greatly depresses the yield. Loew ( $Z$. landw. Versuchsw. Oesterr. 8, 583-602 (1905)) and Loew and Aso (Bull. Col. Agr. Tokyo Imp. Univ. 6, 335-346 (1905)), in investigations upon the ratio of lime to magnesia, find that this ratio is dependent upon equal availability in the forms in which the linie and riagnesia exist, and Loew maintains his well-known views regarding the necessity of having a definite relation between lime and magnesia in the soil in order to insure the highest productiveness. Hoffmann (Arb. deut. landw. Ges. No. I06 (I905)) reports in detail a large number of experiments conducted under the auspices of the German Agricultural Society in which the use of lime in rotation experiments proved beneficial in a majority of cases. On light poor soil in dry seasons carbonates proved preferable to caustic lime. Methods for applying different forms of lime are given. Meyer (Fühling's landw. Ztg. 54, 26I-267 (I905)), having found that crops grown in zinc pots and fertilized with gypsum gave small yields, has repeated his experiments checking the results with earthenware pots and finds that the yield of leguminous crops is much reduced in zinc pots but that the injury was overcome by adding calcium or magnesium carbonate. Tacke (Fühling's landw. Ztg. 54, 33 I (1905)), in referring to the abovementioned work of Meyer's, calls attention to the earlier work of Fleischer and Tacke and Immendorff with gypsum on acid upland moor soils which indicated that the injury was due to the setting free of acids, and claim this is the explanation for Meyer's results. (This same injury has been observed in the work of the Bureau of Chemistry, U. S. Department of Agriculture, and it should be remembered that zinc sulphate which is undoubtedly formed, is of itself a decidedly acid salt and fully capable of producing all the injury observed, if present in sufficient quantity. Careful ex- 
amination renders it doubtful that any quantity of free acid results during the reaction. It seems more plausible, therefore, to attribute the injury to the salt rather than to the free acid. -Reviewer.) Hardt (Deut. landw. Presse, 32, 253-254 (1905)) has published results of four years' culture and liming experiments on moor soils. Sutherst (Chem. News, 92, I85 (1905)) proposes to determine the availability of phosphoric acid in I per cent. citric acid and finds that the presence of soluble salts modifies considerably the solubility in this reagent. Rippert (Fühling's landw. Z tg. 54, 608-620 (1905)) has reviewed the investigations relating to the fertilizing value of different forms of nitrogen, potash and phosphoric acid and points out that in judging of the efficiency of a fertilizer, a number of different factors such as geographical position, climate, amount of precipitation, geological character of the soil, chemical and physical properties, depth of the surface soil as well as the character of the subsoil must be considered.

Notwithstanding the fact that a great deal of work has been done and that the methods at present for the estimation of fertilizer constituents are in a very good shape, a number of investigators have continued to devote considerable time to improvements in methods with a view of shortening the operation or increasing the accuracy of results. Hissink and Van der Waerden (Abs. Chem. Centr. I, II88 (1905)) have so modified the volumetric determination of phosphoric acid as to secure a uniform composition of the yellow precipitate. Hlavnicka ( $Z$. angew. Chem. 18, 655 (1905)) describes a simple modification of Hundeshagen's method, precipitating the magnesium-ammonium phosphate by the citrate method, washing on a hardened filter with $2 \frac{1}{2}$ per cent. ammonia and then with alcohol until free from ammonia, the total volume of washing not exceeding $40 \mathrm{cc}$. The titration is made, using methyl orange as an indicator. Hirt and Steel (Proc. Soc. Chem. Ind. Victoria (1905) I4-I9, and Chem. News, 92, I I3I I4 (I905)) slightly modify Littmann's method, which they consider preferable to Pemberton's for commercial work. Raschig (Z. angew. Chem. $18,374-376$ (1905)) shows that the amount of water used in washing magnesium-ammonium phosphate prior to titration may be reduced to ro cc. Neubauer (Landw. Vers. Stat. 63, 141-149 (1905)) gives a simple method for the determination of phosphoric acid, potash, sodium, calcium and magnesium in hydrochloric acid soil solutions. Schultze (Chem.Ztg. 29, 508 (1905)) estimates calcium oxide and phosphoric acid volumetrically and shortens the regular method for the determination of potash as potassium chlorplatinate.

Schenke (Landw. Vers. Stat. 62, 3-ro (1905)) makes a comparative examination of Märcker's German official citrate method and a modified citrate method for the determination of phosphoric acid in bone meal, Thomas slag and soils. The results 
of the modified citrate method agree most closely with the molybdic method. The author points out that the citrate method is a "compensation method." Mach (Landw. Vers. Stat. 63, 8I-9I (1905)) finds that the Wagner method and the official German method for determining phosphoric acid agree closely as a rule. The Wagner method gave higher results in slag rich in silica. The Schenke modification of the citrate method gave results that were too high. Seib (Z. anal. Chem. 44, 397-398 (I905)) offers a substitute for the Petermann method as used in Belgium, which shows results agreeing quite closely with the Petermann method. Ledoux (Abs. J. Chem. Ind. 24, 904 (I905)) detects natural phosphates in phosphatic slags by extracting the phosphoric acid of the mixed phosphates with citric acid. This dissolves the phosphoric acid of the slag. The residue is treated with nitric acid and if on adding ammonium molybdate to the solution a precipitate is formed, the presence of natural phosphates is indicated. Svoboda (Chem. Ztg. 29, 453-456 (1905)) has made a critical examination of the Maercker-Bühring solution, Wagner's citrate magnesia mixture, and iron citrate magnesia mixture to show their solvent effect on glass. Boulez (5 Internat. Kong. angew. Chem. Ber. 3, 746-747 (I903)) determines phosphoric acid in the presence of other constituents in phosphatic material by titrating with alkali, using methyl orange and phenolphthalein as indicators.

Järvinen ( $Z$ anal. Chem. 44, 333-342 (I905)) determines magnesium in a solution exactly neutralized, using lacmoid as indicator, by the cautious addition of a slightly ammoniacal solution of diammonium phosphate. After standing a short time, I per cent. ammonia is added and then ro per cent. ammonia in quantity equal to one-third the volume of the whole. The determination is made after two hours' standing. Baxter and Griffin (Am. Ch. J. 34, 204-2I7 (1905)) find that the precipitate of anmonium phosphomolybdate occludes a small amount of molybdic acid which renders the results by this method slightly inaccurate. It is also claimed that 24 molecules of alkali are required for the neutralization of one molecule of ammonium phosphomolybdate and not 23 as commonly assumed. The authors conclude that no method for estimating phosphoric acid which depends upon the determination of the molybdic acid in ammonitum phosphomolybdate is accurate unless allowance is made for the occluded ammonium molybdate and molybdic acid. Gerhardt (Chem. Ztg. 29, 178-179 (1905)) determines free phosphoric acid in superphosphates by shaking 20 grams of the superphosphate mixed with I gram of ferrocyanide of potassium dissolved in a little water for one-half hour in a liter of water. Filter, add a known weight of calcium carbonate to roo $\mathrm{rc}$. of the solution and stir for one-half hour. Remove the excess of calcium carbonate by filtering, wash, dry, burn, ignite carefully and weigh. 
The difference between the calcium carbonate used and that thus obtained furnishes a means of determining free phosphoric acid. Zöckler (Chem. 7.tg. 29, 226-338 (1905)) believes that Gerhardt's method is unreliable and considers the alcohol method safer. Ostersetzer (Chem. News, 9I, 2I5 (I905)) briefly describes the method for using alizarinsulphonic acid as indicator in determining free acid in superphosphates.

Westhausser ( $Z$. anal. Chem. 44, I87-I9 I (I905)) compares the official German method, the original Kellner-Böttcher method and the Kellner-Böttcher method, using Hallens ammonium citrate solution. All were unteliable on Thomas slags containing large amounts of silica. Alvarez (Chem. News, 9I, 146 (Igo5)) proposes to use sodium aminonaphtholstlphonate for the precipitation of potash in neutral solutions. The precipitate may be washed in alcohol. Ammonium and magnesium salts do not interfere with the reaction. Klinkerfues (Chem, $Z$ tg. 29, $77-78$ (I905)) estimates potash by direct evaporation of the water solution with chlorplatinic acid and, after washing the potassium chlorplatinate with a very little water and with alcohol, dissolves it in water in a platinum dish and precipitates metallic platinum by decomposing the salt with formic acid. In a later communication (Chem. Ztg. 29, 1085-1086 (1905)) the author states that it is not necessary to completely dry the salt after the addition of formic acid. This, however, greatly shortens the operation. Pfyl (Abs. in Analyst, 30, 345-346 (1905)) determines nitric acid in the presence of organic substances by reducing nitric acid to nitric oxide by means of ferrous chloride and hydrochloric acid, the nitric acid being washed by passing it through sodium hydroxide solution and absorbing by tenth-normal potassium permanganate solution. The excess of permanganate solution is titrated with tenth-normal ferrous chloride solution. Frerichs (Abs. in Chem. Centr. I, 957 (I905)) calls attention to the fact that the reaction between nitric acid and diphenylamine is interfered with by the presence of such substances as ferric salts, chromates, etc., and proposes to obviate some of the difficulty by treatment with ether in sulphurous acid solution. Gutbier $(Z$. angew. Chem. I8, 494-499 (I905)) reports tests of the accuracy of Busch's method for the determination of nitric acid. The Busch method (Ber. $38,86 \mathrm{I}-866$ (I905)) is based on the fact that diphenyleneanilodihydrotriazol forms insoluble compounds with nitric acid and makes it possible to detect this acid in dilutions of $I: 60,000$ at room temperature, and $\mathrm{I}: 80,000$ at zero temperature. A list of other substances forming similar precipitates which may interfere is given. Tests on pure potassium nitrate show a close agreement with standard methods.

Meisenheimer and Heim (Ber. 38, 3834-3837 (1905)) describe a method for the determination of nitric and nitrous acids based upon the measurement of the nitric oxide set free when nitrous acid. 
is treated with hydrogen iodide and when nitric acid is treated with ferrous chloride and hydrochloric acid in the usual way. Raschig (Ber. 38, 39II-39I4 (1905)) claims priority for the above method. Bensemann ( $Z$. angew. Chem. 18, 939 and $\mathrm{I}_{22} 5^{-\mathrm{I}} 228$ (1905)) proposes a method for the complete analysis of sodium nitrate. Easton (Chem. Eng. I, 142-145) estimates nitric acid and nitrates by electrolytically reducing to ammonia in a copper solution acidified with sulphuric acid and distilling the ammonia thus formed.

Schloesing (Compt. rend. I4I, 745-746 (1905)) has compared the value of calcium nitrate prepared electrolytically with sodium nitrate and a mixture of sodium nitrite and calcium nitrite for the production of corn in pot experiments. All the substances were equally valuable in increasing the yield. Thiele (Mitt. landw. Inst. Breslau 3, I57-I 78 (I905)) thoroughly reviews the literature relating to the sampling of soils with particular reference to the difficulty of securing representative samples, showing the small differences occurring in plant-food constituents, particularly nitrogen. The results indicate that it is not possible to get a strictly representative sample by present methods of sampling but that it is possible to detect by analysis smaller variations in nitrogen content than are likely to be of significance in experimental work. Trillat and Turchet (Bull. soc. chim. [3] 33, 308310 (I905)) have examined the nitrogen iodide reaction for determining ammonia in potable waters. They also (Ibid. pp. 304-308) propose a new method for determining ammonia which is based upon the fact that when 3 drops of a Io per cent. potassium iodide solution and 2 drops of a saturated alkali hypochlorite solution are added to 20 or $30 \mathrm{cc}$. of water containing ammonia, a black coloration is formed. Flamand and Prager (Ber. 38, 559560 (1905)) modify Kjeldahl's method to make it applicable for the determination of nitrogen in azo-, azoxy-, and hydrazocompounds. Tschernobajeff (Chem. Ztg. 29, 442-443 (I go5)) recommends that chlorates and perchlorates be determined together in sodium nitrate by Lemaitre's method and that chlorates be determined separately by reduction in the cold by means of iron and sulphuric acid according to Hendrixson's method. Bensemann ( $Z$. angew. Chem. 18, 816 (I905)) proposes to reduce nitrate of soda by fusion with oxalic acid until carbonate is formed, and nitrogen and chlorine are expelled.

SOILS BY F. P. VEITCH.

The chemical investigation of soils has continued to receive its full share of attention, and a number of workers have endeavored to establish a relation between crop production and the plant food constituents removed from the soil by various solvents. Marr (Meded. Proefstat. Oost-Java [4] No. 4, 65--87) finds that many soils of Java, although containing a low percentage of total 
phosphoric acid (less than 0.I), yet produce excellent crops and fail to respond to applications of phosphates. Examination of such soils by the methods of Schloesing and of Dyer (using 2 per cent. citric acid) showed that the former method did not give results agreeing with the crop history of the soil, but that the Dyer method showed the soils to contain sufficient assimilable phosphoric acid. Kudasher (Zhur. Opintn. Agron. 6, 436437 (1905)) finds in the examination of 62 samples of Chernozem soils that the most fertile soils yield the most phosphoric acid to 0.5 per cent. oxalic acid solution. Ingle $(J$. Chem. Soc. 87, 4355 (1905)), from numerous pot experiments with barley, turnips and horse beans, draws the conclusion that while Dyer's I per cent. citric acid method measures the relative available plant food in soils at a given time, it does not necessarily show the relative fertility of the soils, as the rapidity with which the available plant food is renewed may differ with the soil. For comparing soils strbjected to the same climatic conditions the author deems the method valuable, but does not think that soils from tropical climates may be judged by the standards of temperate climates. This latter thought is also advanced by Couturier (Bull. assoc. chim. sucr. distill. 22, I302-I304 (I905)). Hubert (Monit. sci. [4] I9, 582-588 (1905)) discusses the value of, and gives methods for the chemical determination of the fertilizer requirements of soil with particular reference to vineyard purposes, and König (Landw. Vers. Stat. 61, 371-396 (1905)) critically discusses the determination of productiveness and plant food requirements of soils from the physical and chemical standpoints. Yegorovo (Zhur. Opintn. Agron. 6, 315-324 (1905)) finds that a 100 volt current of low amperage passed through the soil greatly increases the solubility of phosphoric acid and of ammonia but lowers that of nitric nitrogen.

Methods for the bacteriological examination of soils have received attention at the hands of Löhnis (Centr. Bakt. $2^{\text {te }}$ Abt., I4, I-9 (I905)) and of Remy (Fi th Internat. Kong. angew. Chem. 784-794 (1903)). Fabricius and von Feilitzen (Szenska Mosskulturför. Tidskr. 19, 84-90 (1905)) find that white moor soils in their natural condition contain but few bacteria, owing to their acid reaction. The bacterial flora is but little changed by drainage but is greatly increased by liming, manuring, admixture of sand and mechanical treatment, and the number of bacteria in a soil is closely related to the temperature, and rises and falls with the latter. It is a well-known fact that soils rich in organic matter are as a rule deficient in available potash, and usually respond readily to applications of potash manures. Recent investigations by Berthelot (Compt. rend. I4I, 433-445 (I905)) show that humus materials treated with solutions of potassium or calcium salts form insoluble salts of these metals, thus rendering them of no value to plants. Minssen (Landw. Vers. Stat. 62, 445-476 (1905)) reviews the literature on diffusion in acid and neutral media, 
with particular reference to the effect of humus soils. The author concludes from the literature and his own work that no acids in dilute solutions interfere with the diffusion of water or salt solutions a conclusion diametrically opposed to that which would be drawn from field or pot experiments with lime on acid clay or humus soils. The influence of lime in increasing the permeability of such soils is too well-known to require discussion, and it would seem that the investigator has missed the point of his work.Reviewer].

Of late years the uses to which peat may be put have increased so rapidly that a discussion of the whole subject is opportunely given by Kerr ("Peat and Its Products," Begg, Kennedy and Elden, Glasgow, I905). Half a century ago the subject of the absorptive power of soils was quite thoroughly investigated. Recently more work has been done along this line by Dittrich (Z. anorg. Chem. 47, I5-I62 (I905)), Dusserre (Chron. agr. vaud. 18, 463-466 (1905)) and by Einecke (Mitt. landw. Inst. Breslau. 3, 299-3IO (I905)) without developing anything particularly new. It is desirable that attention should be redirected to this line of work as from a more thorough and general knowledge of the subject the behavior and effects of fertilizers may be more fully understood. Dittrich's results showing that calcium chloride solutions exert more solvent effect on potash, lime and soda than ammonium chloride or acetic acid solutions are worthy of mention. The water requirements of plants have continued to receive attention at the hands of von Seelhorst and Müther ( $J$. landw. 53, 239-259 (I905)) who experimented with oats, clover and bare fallow, using pots sunk to the level of the ground, and found that, where the ground was kept cultivated, 256.7 grams of water produced I gram of dry matter in oats, while 270.2 grams of water were required on rolled ground. One gram of clover required 423 grams for the first cutting and I, I 24 grams of water for the second cutting. It was found that the loss of nitrogen through drainage was greatest under bare fallow. Murinov (Mater. Izuchen. Russ. Pochv. No. I6 (I905)) has attempted to determine the effect of the action of earthworms on the chemical composition of the soils, and finds the solubility of phosphoric acid in ro per cent. hydrochloric acid is increased in all cases, while the quantity of lime gradually increased in the lower layers of the soil and nitrogen was more evenly distributed than at the beginning of the experiment. Stoklasa and Ernest (Centr. Bakt. $2^{\text {te }}$ Abt., I4, 723-736 (1905)) finds that enormous quantities of carbon dioxide, about r 30 kilos per hectare per day, during the growing season are set free in the soil chiefly through the action of microorganisms and the roots of higher plants, the former producing slightly the most. The authors are of the opinion that this carbon dioxide converts much plant food into soluble forms, 
and that the solvent effect of roots is due to the production of carbon dioxide rather than to the secretion of organic acids.

One of the most valuable, if not the most valuable, contribution to the literature of soils and fertilizers of the year is that of Hall ("The Book of the Rothamsted Experiments," John Murray, London, 1905) who summarizes in a clear and practical way the results of various lines of experiments conducted at Rothamsted for more than half a century. Perhaps the most interesting features, because never brought out before in the papers from Rothamsted, are those tables which bring out the effect of fertilizer residues not only on the yield of crops, but also on the physical condition and chemical reaction of the soil, and also upon the nature of the herbage, the action of bacteria, and the loss of beneficial lime salts in drainage waters. The factors which influence the growth of plants in pots have received attention from Lemmermann ( $J$. landw. 53, I73 (1905)) and also from Voelcker (Ann. Rep. Chem. Soc. London 2, 250-25I (rgo5)) who think that pot experiments should be conducted in triplicate and repeated before accepting them. Lack of agreement between pot and field experiments is attributed to failure to reproduce in pots actual field conditions.

Geological, mineralogical and chemical investigations of soils have been made by numerous workers to which but mere reference can be made here: "Geological Observations on Analyses of Some West Prussian Soils," by Jentzsch (Landw. Jahrb. 34, $165^{-176}$ (I905)); "The Composition of West Prussian Soils," by Schmoeger (Landw. Jahrb. 34, I45-I64 (I905)); "Geological Notes on Cocoa Soils," by Cunningham-Craig (Trinidad Bot. Dept. Bull. Misc. Inform. 196-200 (1905)); "The Mineralogical Analysis of Soils," by Dumont (Compt. rend. 140, IIII-III3 (I905)); "Classification and Nomenclature of Soils According to Mineralogical Constitution," by Lagatu (Compt. rend. I4 r, 363-366 (1905)); "Contributions to the Chemical Study of Soils, Waters and Mineral Products of the Region of Chari and Lake Tchad," by Hebert (Compt. rend. 140, I63-I65 (I905)); "Soil Investigations in the Philippines," by Sanchez (Bur. Agr. Rept. 63-76 (I904)); "Study of Belgian Soils," (Bull. Agr. (Brussels) 2, 85-I2I (I905)); "Some Soil Analyses," by Pardy (Natal. Agr. J. Min. Rec. I8, 573-574 (1905)); "Analysis of Spanish Soils" (Abonos Quimicos. 5, 25-27 (1905)); "Soils of the Argentine Republic," by Cravetti and by Huergo (Am. Min. Agr. Argentina, Sec. Agr. (Agron) I, I2-59 and 2 I-65 (I905)); "Soils," by Ingle (Transvaal Agr. J. 3, 73 I (I905)); "The Sugar Soils of Jamaica," by Cousins (Bull. Dept. Agr. Jamaica 3, 137-146 (1905)); "The Soils of Montserrat," by Watts and Tempany (West Indian Bull. 6, 263-284 (1905)).

The value of mechanical analysis of soils is considered by Atterberg (Chem. Ztg. 29, I95-I98 (I905)), who proposes a new 
classification of the different grades of soil particles, and also by Mitscherlich (Fühling's landre. Ztg. 54, 673-675 (I905)) who, while believing that the determination of hygroscopic moisture and of heat evolved on moistening is of no importance from the standpoint of plant growth, thinks that for judging the character of soils mechanical analysis may be replaced by the determination of the heat evolved on moistening or preferably by determining hygroscopicity. Sjollema ( $J$. landw. 53, 67-69, 70-76 (I905)) proposes to isolate colloidal substances by centrifuging the soil and noting the behavior of the colloids with coloring-matters. The value of the determination of loss on ignition is seriously questioned by Mehring ( $J$. landw. 53, 229-257 (I905)), who thinks that the errors of this determination are increased by attempting to restore carbonates by treating with ammonium carbonate. It is claimed that the direct determination of humus by combustion with copper oxide or chromic acid is more reliable and useful than incineration. A number of articles dealing with the estimation of certain soil constituents have appeared during the year, among which may be mentioned papers by Pellet and Tribourg (Ann. chim. anal. 10, 413-4I6 (1905)); Schultze (Z. landw. Versuchsn. Oesterr. 8, 70-72(1905)); Amos (J. Agr. Sci. I, 322-326 (I905)); Wohltmann and Schneider (Chem. Ztg. 29, 810-8 I I (1905)); Sommer (Deut. landw. Presse, 32, 692 (1905)).

WATER BY W. W. SkINNER.

In the examination of mineral waters the phenomenon of radioactivity has attracted much attention. Blanc (Phil. Mag. 9, I48-I49) examined numerous samples from Alpine regions and found that most of them produced a certain amount of emanation. In some cases the rate of decay was approximately equal to that of the radium emanation. Some of the deposits, however, produced very little or else a very rapidly decaying emanation, from which the author concludes that the latter are probably due to thorium. The Wiesbaden Thermal Springs were examined by F. Henrich (Monatsh. 26, I49-I 84 ) and found to be radioactive. The gases obtained by boiling the waters were radioactive, which phenomenon was much intensified by the removal of the carbon dioxide. The evaporated residue consisting mostly of sodium chloride was found to be only slightly radioactive, but calcium carbonate in the form of aragonite which is deposited from the water at some distance from the spring was found to be strongly radioactive. Mache and Meyer (Monatsh. 26, 595-625) examined some of the mineral springs of Bohemia including Karlsbad, Marienbad and Franzenbad, and found them radioactive. They also found that the rate of decay was about the same as that of radium emanation. The presence of thorium could not be detected. In Karlsbad it was 
found that the cold ferruginous spring situated within the thermal belt contained a greater proportion of radium emanation than any of the hot springs. The waters from the St. Joachimsthal mines were also found to be radioactive, and the activity increased with the depth of the source. The lowest spring was found to contain a larger proportion of radioactive emanation than any water heretofore examined. The Gastein Thermal Springs were examined by Mache (Monatsh. 26, 349-372) and found to be radioactive with a rate of decay approximately equal to that of the radium emanation. The active substance was found to be the reissacherite of the deposits from the thermal springs. This mineral nearly equals uranyl nitrate in activity, and contains barium, strontium and calcium, but no uranium. Upon separation the radioactive substance is found along with barium and is presumably radium.

Brown (J. Chem. Soc. 87, I05I) reviews critically the Frankland combustion method, the Wanklyn albuminoid ammonia process and the Tidy permanganate method, pointing out the advantages and disadvantages of each. He believes that neither the Wanklyn nor the oxidation method alone, gives any idea of the source of the organic matter. To correct this he suggests a method by combining the Frankland and Wanklyn methods and by so doing obtains the whole of the carbon and nitrogen of the organic matter, in the form of carbon dioxide and ammonia, determining the quantity of each. The author presents considerable data to substantiate his claims for the method, from which he concludes that the new method is as precise as Kjeldahl's and is more applicable to water, requiring a smaller sample, eliminating the use of sulphuric acid and avoiding all bumping in glass vessels. It also requires less time and attention without sacrificing accuracy.

According to Effront (Chem. Centr. 2, 1253) on the addition of a definite quantity of bleaching-powder, which has been accurately titrated, to a given volume of water, the loss in active chlorine is a measure of the nitrogen of the ammonia and proteids. The diphenylamine reaction for the detection of nitric acid in waters is proposed by G. Frerichs (Arch. Pharm. 243, 80). It is claimed that ferric salts, chromates, etc., do not interfere with the reaction. Franz Utz (Chem. Ztg. 29, 177) proposes an improvement upon the above method of Frerichs by evaporation with hydrochloric acid, claiming that with this modification the method gives results favorably comparable with the methods of Schulze-Tiemann and Mayrhofer. A method for the detection of nitrous and nitric acids by means of diphenylamine is also proposed by Raikow (Chem. Centr. I, 402). The estimation of ammonia by the method of Trillat and Turchel is claimed by Cavalier (Bull. soc. chim. 33, 745) to be worthless for quantitative work. He believes the method can 
be used only after considerable concentration, and even then the nature of the precipitate renders the estimation very difficult. F. Dienert (Ann. inst. Pasteur, 19, 541) discusses various methods and describes in detail a method based upon electric conductivity, which it is claimed is well suited to the study of variations of underground waters. A modification of the Winkler method for determining oxygen in water is proposed by Noll ( $Z$. angew. Chem. 28, 1767) by which more accurate results may be obtained. The purification of water by means of barium carbonate is proposed by Basch (Chem. Ztg. 29, 721). The advantages which are claimed for this procedure are that the permanent and temporary hardness are removed, as well as all the sulphates. This is not the case when caustic lime and sodium carbonate are used for this purpose, one of the results of the latter metathesis being the formation of sodium sulphate which is objectionable for a number of reasons. Calcium peroxide has been proposed by Freyssinge and Roche (Rev. internat. falsif. 28, 49) for the sterilization and purification of drinking-water. It is stated that water can be completely sterilized in about two hours by the addition of 0.4 gram of calcium peroxide per liter.

FeEding Stuffs by W. W. Skinner.

In the proximate analysis of feeding stuffs the attention of investigators is constantly being directed towards that class of substances coming under the caption of nitrogen-free extract, in an effort to more definitely determine the several components of this subdivision. The method of Ellett (Inaug. Diss. Univ. Göttingen 1904) for the quantitative estimation of pentosans and methylpentosans is an instance of this effort. The method proposed is a simultaneous determination of methylpentosans and pentosans in vegetable products. He confirms Votocek's statement that methylfurfural phloroglucide, even when dried, is soluble in alcohol, while furfural phloroglucide is not. Upon this fact he bases his method by obtaining the two together and weighing, and then dissolving out with alcohol the methylfurfural phloroglucide and again weighing. Details of the method are given and the data offered indicate that the method, as worked out, gives satisfactory results. V. Storch (Ber. Vet. Land. Lab. Landökonom. 58, 180) explains in detail the methods employed in the analysis of feeding stuffs by the chemical department of the Copenhagen Experiment Station. The faults of the conventional methods for determining nitrogenous components, crude fiber, and nitrogen-free extract are pointed out and discussed. The author recommends that the following determinations be made, viz., fat, albuminoids, sugar, starch, pentosans, ash, and water, with cellulose and other undeterminable substances grouped by difference. This scheme is now employed at the Copenhagen Station. J. König (Internat. Kong. angew. Chem. 
5, I052) describes his method for the determination of crude fiber in foods and feeding stuffs by means of a mixture of glycerol and sulphuric acid. The amount of lignin in the crude fiber is determined by hydrogen peroxide and ammonia, which dissolves the lignin, leaving the pure cellulose. An exhaustive study of the value of sorghum seed as a feeding stuff has been made by Tangl, Weiser and Zartschek (Landw. Jahrb. 34, 3-64). The authors experimented with horses, steers, cows, sheep, pigs and poultry, and in addition to studying the digestibility of the seed, the income and outgo of nitrogen were determined. From their work they consider sorghum seed a valuable feed, but that to attain the best results it should be mixed with some other grain. Especially is this true for horses.

\section{Cereals bY J. S. Chamberi.ain.}

One of the important contributions of the year to the chemistry of cereals is the monograph by F. F. Bruyning, Jr., ("La valeur boulangere du froment," Archives Teyler [II], 9, Parts 3-4, Haarlem (1905)) on the baking value of wheat. It is a book of 217 pages and its object is to give a view of the actual state of our knowledge of the baking properties of different kinds of wheat, especially from the point of view of the milling and baking industries of Holland. E. Fleurent has published under different titles (Ann. chim. anal. Io, I29, 195, 238, 276 and 309 (1905), (Compt. rend. I40, 99 (1905)) a 'resumé of his work for several years on the determination of gluten. He draws the following conclusions: (I) Wheat gluten is a definite substance and its mechanical extraction, if carried out under proper conditions, is definite and exact. (2) Distilled water and water containing calcium chloride or sulphate or sodium chloride cause a loss in the determination of gluten, but this loss is lessened if calcium bicarbonate is present. (3) In determining gluten only the soluble proteids are lost in the washing and not the gluten. If calcium chloride or sulphate is present in the wash-water the amount of gluten lost is proportional to the amount of globulin present. (4) Prolonged washing causes a loss in gluten and the gluten so lost always contains gliadin and glutenin in the proportion of $75: 25$. (5) The acidity of old flours tends to lessen the ease of washing out the gluten but neutralization of the excess acidity by means of sodium bicarbonate makes the determination satisfactory. (6) Allowing the mixed dough to stand before washing tends to loss of gliten. ( 7 ) The amounts of gluten extracted at temperatures between $15^{\circ} \mathrm{C}$. and $35^{\circ} \mathrm{C}$. are practically the same. (8) Water at $16^{\circ} \mathrm{C}$. containing $80-90 \mathrm{mg}$. of salts per liter, of which $80-90$ per cent. is in the form of calcium bicarbonate, is the best for washing out gluten. The washing should take ten to eleven minutes and the final washing two to three minutes. The gluten shotuld be dried at $105^{\circ} \mathrm{C}$. Results should 
agree within 0.20 per cent. The influence of the constituents of brown or low-grade flour on the determination of gluten has been examined by Lindet and Amman (Compt. rend. I4I, 56 (1905)) who find that among other things there is present in dark flour a mucilaginous substance which prevents the gluten from adhering together as usual. A determination of the hydrolytic cleavage products of the protein "gliadin" by means of dilute acid has been made by E. Abderhalden and F. Sammely $(Z$. physiol. Chem. 44, 276 (I905)). They find, as did Osborne and Harris (Am. J. Physiol. I3, 35 (I905)) by practically the same method, that by far the greatest part of the cleavage products obtained is in the form of glutamic acid. They find 3I.5 per cent. of glutamic acid while Osborne and Harris found 37 per cent. Also that gliadin yields none of the diamino acid lysine and therefore differs sharply from the alcohol-insoluble protein gluten casein (glutenin) which yields a considerable quantity. The amino compounds obtained as cleavage products of gliadin are as follows: Glycocoll, 0.68 per cent., alanine, 2.66 per cent.; aminovaleric acid, 0.33 per cent.; $a$-proline, 2.40 per cent.; leucine 6.00 per cent.; glutamic acid, 27.60 per cent.; aspartic acid, I.24 per cent.; phenylalanine, 2.60 per cent.; serine, 0.12 per cent.; tyrosine, 2.37 per cent.; tryptophane, I.00 per cent.

Chapus (Bull. Agr. Algerie et Tunis, No. 7, I I (I905)) discusses the views held and advanced especially by Fleurent and Balland in regard to the differences in composition between hard wheats and soft wheats, the relation of protein content to yield, the determination of gluten and the significance of the proteins gliadin and glutenin. Physiological experiments with man and the nutritive value of different kinds of flour have been made by P. Fauvel (Compt. rend. 140, I424 (1905)), who finds, from results obtained using white flour, whole wheat flour and brown army flour, that whole wheat bread, though containing more than twice as much phosphoric acid as the army bread, yet does not yield as much assimilable phosphoric acid as the latter. The whole wheat bread diminished the excretion of urea and produced an appreciable quantity of purine bodies. It also irritated the intestines and diminished the assimilation of other nutrients. The army bread was superior to the white and possessed none of the undesirable properties of the whole wheat bread. A case of poisonous flour made from rye infested with a fungus, $F$ usarium roseum, was reported by A. Yachevski (Russ. J. exp. landw. 6, 249 (I905)).

Work on barley and malt has been carried on by several investigators. Vanha, Kyas and Bukovansky ( $Z$ tg. landw. Versuchsw. Oesterr. 667 (1905)) have demonstrated that seed of high nitrogenfree extract, low total protein and high soluble protein content gave a crop of increased total yield, an increase in yield of grain, number and weight of stalks and total weight of heads. This 
influence is explained by the fact that the nitrogen-free extract acts as reserve material and that the best developed embryo is found in seed of high nitrogen-free extract. They conclude that neither nitrogen-free extract nor protein content are transmitted characters but depend chiefly on the quality of soil and the supply of plant food. Other investigations on the relation between protein content and yield have been made by Schneidewind (Wochenschr. Brau. 22, 29 (I905)), who maintains that with barley as with other plants the higher the yield under like conditions the lower the protein content. He claims that this is explained by the fact that in the first and middle period of growth large amounts of nitrogen are assimilated and if growth is then suddenly checked the formation of starch is hindered and the nitrogen content will be high. The bettering of the quality of barley by a mechanical and chemical study of the composition of barley soils has been undertaken by J. Stoklasa (Chem. Centr. I905, I, 761 ). According to the author the rôle of potash in starch formation is such that the amount of potash assimilated stands in a constant ratio to the amount of starch in the grain. One gram assimilated potash produces 23 to 25 grams of starch. The best brewing barleys and their relation to crop rotation and fertilizers have been investigated by $\mathrm{E}$. Schribeaux (Ann. brass. dist. 8, I 85 (1905)), and the abnormal character of the barley of the crop of 1904 and beer produced from it has been studied by W. Windisch (Wochenschr. Brau. 22, 373 (I905)). The turbidity of the "White" beers obtained may be due either to abnormal albuminoid bodies or to abnormal carbohydrates such as pectins. If due to albuminoid bodies they must be compounds intermediate between albumins and albumoses.

A modification of Lindet's method for the examination of malt has been published by Ford and Guthrie (J. Inst. Brew. (London) II, 206 and 326 (I905)). A study of methods for the ash determination of malt has been made by W. Windisch (Wochenschr. Brau. 22, I7 (I905)). The enzymes of malt have been investigated by W. Issajew (Z. physiol. Chem. 45, 33 I (1905)), who concludes that there is present in barley and malt a substance possessing all the properties of an oxydase. The ease with which it accelerates oxidation, its relation to temperature and toward reagents, its "Spezifität," etc., all serve to show its enzymic nature. Its rôle in various physiological processes, especially in germination, is doubtless very important. J. Effront (Compt. rend. I4I, 626 (I905)) finds that during germination of malt the saccharifying power and the liquefying power of diastase are developed unequally. The saccharifying power increases irregularly and after having attained its maximum diminishes gradually. The development of the liquefying power is slower but more regular and on reaching its maximum it is maintained for some time. When germination is produced in sunlight the difference in the develop- 
ment of the two powers is very marked. These phenomena evidently have a direct relation to the transient formation of acid amides during germination. The action of chemical agents on the germination of barley is very complex. Phosphates, lime water and copper sulphate favor germination. Xylene acts favorably toward both saccharifying power and liquefying power. Ammonium chloride increases the liquefying power. Lactic acid, vegetable peptone and neutral calcium hypochlorite increase germination and both enzymic activities but if the calcium hypochlorite is alkaline, it favors germination but weakens the diastatic power.

A study of the value of different sized kernels of rye for baking and feeding purposes has been made by Bastecky (Chem. Centr. $1905, I, 465)$. The influence of soil moisture on the composition of oats has been investigated by Seelhorst and Fresenius ( $J$. Landw. 53, 2 I (1905). Their conclusions from pot experiments are: Straw grown on dry soil is characterized by a high digestible protein content. The albuminoid nitrogen diminishes less with increasing moisture content of soil than do the total nitrogenous bodies. The digestible protein diminishes more rapidly than the total protein. The increase in ash and organic matter during the growth of oats has been examined by M'lle Stefanowska (Compt. rend. I40, 58 (1905)). The curves representing the increase in fresh substance, dry substance and ash all have a similar character, increasing slowly per day of growth at first and during maturity increasing very rapidly. The same is true of organic nitrogen, phosphoric acid, lime, potash and iron. An important contribution to our knowledge of the chemical composition and nutritive value of sorghum seed and oats is that by $F$. Tangl, of the Experiment Station for Animal Physiology of Budapest, and his associates (Landw. Jahrb. [3] 34, 65 (1905)). The coefficients of digestibility of sorghum on steers, sheep, horses and swine, and of oats on horses and sheep are given for each constituent. The average composition and nutritive value of both feeds are also given in numerous tables. They calculate the physiological nutritive value of oats fed to horses as 54.80 per cent., with sheep 53.85 per cent. Sorghum grain alone is not a satisfactory feed for horses, but if fed with twice its weight of oats, it is good. Becquerel (Compt. rend. I40, I652 (I905)) has shown that the effect of low temperature upon the vitality of various leguminous and cereal seeds depends upon the amount of water and gas present in the seeds. As the result of experimental work Dumont (Compt. rend. I4r, 686 (I905)) concludes that the rays of light which act the most effectively upon the migration of albuminoids in grain are those which have the least effect on the chlorophyll function, viz., dark brown, green, blue, red, in the order given. The aleurone grains found in cereals and other seeds have been studied by S. Posternak (Compt. rend. 140, 322 (1905)). The aleurone 
grains are formed during the maturity of the seed when the kernel is drying out. The common conception that the aleurone grains are reserve nitrogenous material of the seed is not in accord with the facts. About 5o to 75 per cent. of the aleurone grains are proteid material, but the 25 to 50 per cent. of the non-proteid materials play an important part in the life of the embryo plant. The author finds a new organic phosphorus compound, viz., anhydrooxymethylene diphosphoric acid or "phytin" and also an organic acid yielding a reducing sugar by hydrolysis. An elementary analysis of aleurone grains from various seeds shows that they contain a considerable quantity of all those mineral elements considered indispensable to the development of a plant. The author claims, therefore, that the aleurone grains are not simply a source of reserve nitrogenous material, but that they are a complete mineral food for the embryo plant, and that the mineral elements are present in the seed, as in the case of phosphorus cited above, in organic combination.

For the detection of sawdust in flour Paganini (Chem. Ztg. Rep. 23 (1905)) recommends the addition, to a thin layer of the flour, of a few drops of a 20 per cent. aqueous solution of phenylendiamine followed by a few drops of acetic acid. A bright yellowish red color is formed in the presence of sawdust. The reagent is claimed to be much more delicate than phloroglucin and hydrochloric acid. In the examination of noodles and other edible pastes, Filsinger ( $Z$. öffentl. Chem. I I, 332) and Luthrig (Z.Nahr.-Genuss. I0, I 53 (I905)) suggest the determination of lecithin. Phosphoric acid does not afford sufficient data for judging of the nutritive value of noodles. A fairly complete proximate analysis is suggested as well as the determination of digestibility.

\section{FOODS BY W. D. BIGELOW.}

Spices, Etc.-Jaeger (Z. Unters. Nahr.-Genuss. ro, 761-762 (I905)) has discussed at considerable length methods for the detection of cocoa shells in spices. The literature of the subject is reviewed. The presence of reducing sugar in mace has afforded the opportunity, which has not been neglected, of adulterating the product with sugar. Ludwig and Haupt (Z. Unter. Nahr.Genuss. 9, 200-204 (I905)) examined a series of samples of mace and found a dextrorotary reducing sugar, the amount present varying from 1.65 to 4.28 per cent. Windisch (Oesterr. landw. Vers. Wes. 8, 74) has continued his study of the ash of paprika, and has compared the results of a microscopic analysis with the chemical results on the content of ash and sand in the samples. His former conclusions are confirmed. A high content of sand is regarded as sufficient ground for condemnation. Süss (Pharm. C. H. 46, I 59) calls attention to the custom in the retail trade of selling underground pimento superficially colored with ochre, or 
similar bodies. The adulteration can frequently be detected by a lens as well as by the examination of the ash. For the determination of artificial coloring-matter in prepared mustard and powdered mustard, the same writer (Pharm. C. H. 46, 291) shakes 50 grams of the sample with $75 \mathrm{cc}$. of 70 per cent. alcohol, filters, and makes the ordinary dyeing tests. In case the wool does not take on a marked color which is altered by either ammonia or hydrochloric acid, he concludes that no artificial coloringmatter has been employed. Filter-paper is also dipped into the solution, dried, and tested with hydrochloric acid and ammonia.

Coffee and Cocoa Preparations. - The soluble glaze on 32 samples of roasted coffee was examined by Orth (Z. Unters. Nahr.- Genuss. 9, I37 (I905)) according to the method suggested by Hilger. $\mathrm{He}$ finds that candied coffee produced by roasting with the addition of sugar, and so distinguished from ordinary glazed coffee, contains from 5 to 7.7 per cent. of soluble material. The standard of 4 per cent. that has been suggested as a maximum will thus not apply to candied coffee. Ottolenghi (Atti della $r$. accademia dei fisiocritici [4], I5, (1903) I I pp. Reprint) calls attention to the frequent use of the seeds of Astragalus boeticus, and suggests the microscopic detection of the latter in the portion of the sample that sinks to the bottom of water. Balland ( $J$. pharm. chim. [6] 20, 543-549 (1904)) and Puckner (Pharm. rev. 23, 305-309 (I905)) discuss the determination of caffein. A study of the chemical and microscopical nature of coffee substitutes prepared from unmalted and malted grain has been published by Prillach (Z. Unters. Nahr.-Genuss. Io, I I 8 (I905)). Filsinger ( $Z$. offentl. Chem. II, 8-1o (1905)) discusses the composition of "soluble" cocoa, and directs that the soluble alkalinity must be determined and not the total alkalinity, which gives too high results. The same subject is discussed by Fröhner and Liuhrig (Z. Unters. Nahr.-Genuss. 9, 257 (1905)) and by Lührig (Z. Unters. Nahr.-Genuss. 9, 267 (1905)). According to Kuhl (Pharm. Ztg. 63I (I905)) the microscopic examination is valueless for determining the variety of cocoa beans employed, or the presence of an excessive amount of cocoa shells. Quantitative examination alone can determine the latter point.

Vegetables.-Frerichs and Rodenberg (Arch. Pharm. 243, 675683 (1905)) give the results of the examination of peas at various stages of their maturity, and of canned peas, and discuss the application of the results to the inspection of the product. Riess (Arbb. kais. Ges, A. 22, 663-666 (I905)) has investigated the compound formed by the action of copper salts in the greening of peas, and methods for the detection of copper. He suggests that copper may be determined by macerating with water, strongly acidifying with hydrochloric acid, and separating by means of iron. The result of the examination of frozen potatoes has been given by Parow ( $Z$. Spiritusind. 28, 405 (1905)). Wintgen (Z. Unters. 
Nahr.-Genuss. ro, 757-761 (1905)) has reported an interesting case of the swelling of canned goods without any appearance of decomposition. The examination of samples shows the excessive gas to consist largely of hydrogen, and masses of a dark colored product which proved to be chiefly phosphate of iron were found in patches at the side of the receptacle. The author concluded that the nature of the sample was due to the action of the acid upon the imperfectly plated iron, an iron salt being formed with the elimination of hydrogen.

Fruit Products. - The year has been marked by a largely increased number of analyses of fruit products of various descriptions for the purpose of securing data for the establishment of standards. A. Beythien (Z. Unters. Nahr.-Genuss. 10, 339 (1905)) has studied the relation between the composition of fruit juices and the alkalinity of their ash. He confirms the earlier belief that the ratio of ash to alkalinity lies between I to Io and I to I5, rather than in the neighborhood of I to 5.3 as has been said by Evers. A method for the preparation of fruit juices and standards of composition have been adopted by the association of German food manufacturers and dealers (Pharm. $2 \mathrm{tg} .380$ (1905)). A. and M. Dominikiewicz (Z. Unters. Nahr.-Genuss. ro, 735-744 (I905)) called attention to the relation between viscosity and refractive index of fruit juices and fruit sirups. They believe that the determination of vicsosity and index of refraction are sufficient for the examination of these products with reference to their purity. Otto and Tolmacz (Z. Unters. Nahr.-Genuss. 9, 267 (I905)) find the unfermented beverages on the market to be grossly adulterated. Some are prepared from dried fruit and others are entirely artificial. Further studies regarding the normal composition of fruit juices and standards for the same have been conducted, especial attention having been given to raspberry juice. Complete analyses have been made of the products of 1905 of the various localities prepared in a different manner. The results published are of great value for the establishments of standards for the inspection of fruit products. Among the chief contributors are P. Buttenberg ( $Z$. Unters. Nahr.-Genuss. 9, I4r-r 45 (I905)) ; F. Morschöck (Z. Unters. Nahr.Genuss. 10, 733-735 (1905)); E. Baier (2. Unters. Nahr.-Genuss. ro, 73 I-732 (I905)); A. Juckenack (Z. Unters. Nahr.- Genuss. I0, 729-730 (I905)); A. Beythien and L. Waters (Z. Unters.- Nahr.Genuss. ro, 726-729 (1905)); H. Lührig (Z. Unters. Nahr.-Genuss. Io, 714-726 (1905)).

Wine.-Windisch and Roettgen (Z. Unters. Nahr.-Genuss. 9, 70-8I (1905)) have published a systematic review of the methods for the determination of volatile acids. They call attention to the fact that the arbitrary method commonly employed for this determination gives incomplete results because of insufficient distillation. They recommend that the distillate be increased 
to $300 \mathrm{cc}$. They also call attention to the fact that lactic acid passes over with steam with some difficulty, and discuss its influence on the determination of volatile acids in wine. The same authors (Z. Unters. Nahr.-Genuss. 9, I29-I33 (I905)) studied the changes in composition of wine occasioned by the use of different clarifying agents. They conclude that the composition of wine is only slightly modified, especially in the case of isinglass and gelatin. Beneschoosky (Z. landw. Versuchsw. Osterr. 8, 78-82 (I905)) called attention to the high volatile acid content of Italian wines. Out of 30 samples examined from various districts in Italy, 12 contained less than o.I per cent. of volatile acids, and I 8 between 0.1 and 0.3 per cent. Of 9I 3 samples of German wines examined 90 per cent, varied within the limits of 0.01 and 0.069 per cent. The amount of succinic acid in 15 samples of Italian wines is reported by Prandi (Staz. sper. agr. ital. 38, 503) as from 0.0820 to I.IIO3 per cent. In the majority of cases it varied from 0.03 to 0.13 per cent. Krug (Z. Unters. Nahr. Genuss. 10, 4I 7 (1905)) determined the sodium content in a series of samples of wine. The maximum content found was $6 \mathrm{mg}$. In over 80 per cent. of the samples examined less than I per cent. of sodium was found. According to Partheil (Fifth Internat. Kong. angew. Chem. Ber. 3, Ior9-IO22 (1903)) the usual method for the determination of lactic acid in wine neglects the fact that acid is volatile with steam. He suggests the precipitation of tartaric, citric, and succinic acids with barium salts. Lactic and acetic acids may be distilled from the filtrate with steam. Pairault (Bol. Camara Com. Asunción, Paraguay [15] (1904)) has studied the manufacture of orange wine. As ordinarily conducted the fermentation is slow because of the absence of sufficient materials for the nutrition of the yeast cells. The writer suggests the addition of sugar and mineral salts. Kramszky (Z. Unters. Nahr. Genuss. 10, 67I (1905)) has reported the composition of raisins and discussed the same with reference to the manufacture of raisin wine. Ruff and Jeroch (Chem. Ztg. rep. 74, 1905) calls attention to incomplete results obtained in the direct titration of sulphurous acid, owing to the oxidation of sulphites by the oxygen of the air.

Distilled Liquors. - Schidrowitz ( $J$. Chem. Ind. 24, 176-178 (1905)) discusses standards proposed for the composition of distilled liquor. He suggests as suitable maximum standards 40 $\mathrm{mg}$. of total acids (calculated as sulphuric acid), 0.3 gram of fusel oil, and 0.25 gram for extract. A board of control and rigid inspection are suggested. The manufacture of alcohol from grape pomace is suggested by Perkins and Jamieson ( $J$. Dept. Agr. So. Aust. 9, 24-38 (1905)). It is stated that the pomace should give about 32 gallons of proof spirit per ton, 80 per cent. of which may be recovered by leaching and fermenting. The methods of manufacturing brandy from various fruits are 
discussed by Windisch (Deutsche Essigindustrie 9, 89-9I (1905)) and Kayser and Dienert (Ann. science agron. [2] 10, 209-2 I9 (1905)). A study of the bacterial action that occurs during the fermentation is included. Contributions to the literature of the examination of distilled liquors have been made by Hehner (Analyst, 30, 36-56 (I905)), Rocques (Ann. chim. anal. Io, I03I08 (1905)), Beckmann (Z. Unters. Nahr.-Genuss. Io, I43-I 52 (1905)) and others.

Vinegar. - Jonscher ( $Z$. offentl. Chem. I I, 467-473 (I905)) discusses standards for wine vinegar. He believes that little can be accomplished by analytical data. Froehner (Z. Unters. Nahr.-Genuss. 9, 361-363 (1905)) considers lactic acid as a normal constituent of wine vinegar, and suggests that the amount of that substance present may be of value in judging the quality of the product. For the same purpose Fresenius ( $Z$. Unters. Nahr.Genuss. Io, I2 I-I29 (I905)) and Möslinger (Z. Unters. Nahr.Genuss. I0, I25 (1905)) suggest the determination of glycerol. The amount of glycerol in wine is not reduced in the manufacture of vinegar. Maustbaum (Revista chim. pura app. 1905, p. 8) suggests the detection in wine vinegar of acetic acid made by the distillation of wood by means of the furfural reaction and the reduction of permanganate. The latter is believed to be the better of the two methods.

Preservatives.-An unusual amount of attention was given during the year to the question of detecting preservatives in food. The tendency to the quantitative detection is very noticeable. Considerable attention has been paid to the effect of preservatives on nutrition and health, and on the whole the tendency of hygienists is evidently more adverse to the use of preservatives than formerly. During the last year the subject of the determination of boric acid has proved an interesting field of work to a large number of men. The literature of the quantitative determination of boric acid has been thoroughly reviewed by Windisch (Z. Unters. Nahr.-Genuss. 9, 64I-660 (1905)) who suggests the elimination of the difficulty occasioned by the use of two indicators with the consequent error, owing to the presence of traces of phosphoric acid that cannot be removed. He proposes the neutralization of the solution by means of iodine and thiosulphate solution, according to Jones, and the titration of the boric acid (which is then free) with phenolphthalein as indicator. (The results of the method outlined by him, however, have not met with general satisfaction at the hands of other workers.-Reviewer.) Fritzsche (Apoth. Ztg. 20, 856 (I905)) believes that a positive reaction for boric acid by the turmeric paper test is sufficient for the condemnation of the sample, and that negative results may readily be obtained in the absence of boric acid by the use of pure reagents. Fendler (A poth. Ztg. 20, 868 (r905)) called attention to the fact that boric acid may be detected in a solution con- 
taining 0.005 per cent., and suggests that it should only be reported as present when a strong reaction is obtained. He believes that traces may occur in normal meat, or result from the salt employed in packing it (see this Journal, 28). He suggests (Apoth. Ztg. 20,757 (1905)) that the best results are given by a solution containing Io per cent. of hydrochloric acid, and suggests a Io per cent. solution of ammonia for the confirmatory test. He proposes the preparation of turmeric paper by immersing strips of turmeric paper in a solution of 0.05 gram of curcumin in Ioo cc. of absolute alcohol, and drying in the dark. He calls attention to the fact that the flame test is not nearly so delicate as the turmeric paper test. He suggests that where an evident flame test is obtained it is sufficient without confirmation, but states that this test is. not without objection because of its subjective nature. He also suggests that in place of turmeric, safflower and marigold may be used as boric acid reagents. Goske (Z. Unters. Nahr.-Genuss. Io, 242-243 (I905)) suggests the method for the detection of boric acid which was originally proposed by Howard (Science 19, $5^{8} 3$ (1904)) for the detection of curcumin. He states that by this method boric acid may be detected in solutions varying from $0.00 \mathrm{I}$ to $0.000 \mathrm{I}$ per cent. (This method has also been employed by Bigelow and Brinton for the quantitative determination of boric acid.) Mezger (Z. Unters. Nahr.-Genuss. ro, 243-245 (I905)) proposes a modification of the flame test for boric acid. He adds to the ash in a flask $2 \mathrm{cc}$. of strong hydrochloric acid, and from I 5 to $20 \mathrm{cc}$. of methyl alcohol. The flask is then attached to a reflux condenser and heated on a water-bath at least $70^{\circ}$ for one-quarter of an hour. If hydrogen be passed through the mixture after cooling, the boric acid compound is carried with it, and may be detected by the color of the flame. O. von Spindler (Z. Unters. Nahr.-Genuss. Io, 478-482 (1905)) reviews the literature on the determination of boric acid and proposes a new apparatus for the flame test. Blarez (Chem. News I905, p. 39) has proposed a modification of the method ordinarily employed for the detection of fluorides in wine. $\mathrm{He}$ finds they may be more completely precipitated by barium salts than by calcium salts, and suggests the addition of barium acetate after adding a small amount of soluble sulphates. The precipitate is settled by centrifuging, separated by filtration, and ashed, after which the usual method is employed. The influence of formaldehyde on fermentation has been studied by Hirsch (Allgem. Z. Bierbrauerei Malzfabrik. 1905, Aug.) and new methods for the detection of formaldehyde, or modifications of old methods have been proposed by Lyons (Pharm. J. 75, 443 (I905)), Voisenet (Bull. soc. chim. 33, II98-1214 (1905)) and Nicolas (Compt. rend. 58, 697-698 (1905)). The last-named suggests that the greenish fluorescence obtained in milk containing formaldehyde by the addition of amidol will permit the 
recognition of the preservative in quantities of $\mathrm{I}$ to 500,000 , or less. Before applying the reagent the milk is clarified with acid, and the filtrate is employed. Schuch ( $Z$. landw. Versuchw. Oesterr. 8, I058-1060 (1905)) made a comparative study of methods for the detection of formaldehyde and gave his preference to that of Arnold and Mentzel. Considerable attention has been given during the year to the use of hydrogen peroxide as a preservative. The literature of the subject has been reviewed by Lukin (Centr. Bakt. 15, 20-32 and 165-174 (1905)). E. von Mahler (Chem. Ztg. 29, 32 (I905)) proposes the detection of saccharin by fusing the residue from the ether extract with sodium or potassium, extracting the sulphide so prepared from the charred mass by means of water and pouring the solution into a solution of sodium nitroprusside. The red-violet color so obtained is a certain indication of the presence of saccharin since no other compound containing sulphur and soluble in ether is present in food. Grimaldi (Staz. sperim. agron. ital. 38, 61 8 (1905)) gives the results of the quantitative determination of salicylic acid in several fruits, and a partial review of the literature relating to the distribution of salicylic acid in nature. The disappearance of sulphurous acid in wine is discussed by Carles (Rep. Pharm. [3] 17, 97-IO2 (I9O5)). Methods for the determination of sulphurous acid in foods were compared by Schumacher and Feder (Z. Unters. Nahr.-Genuss. Io, 649-659 (I905)). The ordinary method of distillation was found to give satisfactory results. The suggestion that the results obtained by the method are influenced by the sulphur content of illuminating gas used in the operation was put to a severe test. It was found that no inaccuracy was occasioned by the gas burned in the room in which the operation was conducted.

Meat Products.- -The methods for the determination of saltpeter in meat preparations have been studied by $E$. Crespolani (Bull.chim. farm. 44, 697-700 (1905)), K. Farnsteiner (Z. Unters. Nahr.-Genuss. I0, 329 (1905)), and W. Stüber (Z. Unters. Nahr.Genuss. I0, 330 (1905)). It has been shown that when I gram of potassium nitrate is added to 300 grams of meat it is reduced first to nitrite and then to ammonia. The Ulsch method was found to be entirely unreliable for the determination of potassium nitrate because of the effect of the reagents on proteids. By the SchlösingWagner method from 99.58 to IO2 per cent. of the nitrate present was recovered. E. Carlinfanti and A. Manetti (Archivio di farmacol. sperim. scienze affini, 4, heft 7-8) made a systematic examination of canned meats for the Italian army. They regard canned meat as less digestible than fresh meat and explain the repugnance that has been experienced after a continuous diet of canned meat to its large fat content. Ground cereal products have been reported by $\mathrm{H}$. Matthes (Z. Unters. Nahr.-Genuss.9, 732 (I905)) as adulterants for corned beef. M. Toyonaga (Bull. Col. 
Agr. Tokyo Imp. Univ. 6, 89-95 (1904)) has summarized the results of other investigators with reference to the calcium content in the different animal tissues, and discussed its relation to magnesium. Klikton (Z. Unters. Nahr.-Genuss. Io, I59 (1905)) has investigated the number of errors in the determination of sulphites in meat, owing to the sulphur content of the gas employed. $\mathrm{He}$ finds that in a room of 109 cubic meters no appreciable amount of sulphurous acid could be detected after nine gas burners had been employed for ten hours.

Meat Extract.-M. Siegfried and E. Singewald (Z. Unters. Nahr.Genuss. I0, 52 I-527 (1905)) pointed out that the deterioration of meat extract is accompanied by the conversion of organic phosphorus into the inorganic form. After a series of analyses of extracts of known origin they suggest that the quality and age of an extract may be judged by estimating the total phosphorus and organic phosphorus. K. Micko (Z. Unters. Nahr.-Genuss. Io, 393 (I905)) has applied Fischer's ester method of hydrolyzation to the determination of the presence of polypeptids in meat extracts. Kutscher (Centr. physiol. r9, 504 (I905)) has made a careful study of the various meat bases in meat extract. He concludes that such products do not have a uniform composition and bodies are sometimes found in it which are not necessarily constituents of muscular tissue. He identified ignotine, methylguanidine, carnomuscarine, neosine, novaine, and oblitine. Barral (J. pharm. chim. [6] 22, 392-395 (I905)) reports the analysis of a so-called papayin meat powder.

Separation of Proteids.-H. C. Haslam (J. Physiol. 32, 267-298 (1905)) has suggested new methods for the separation of proteid bodies which he regards as more exact than those commonly employed. He believes that the methods now in use afford results that are far from satisfactory, owing to the tenacity with which the various proteid bodies cling to each other. This tenacity he explains by the supposition that a loose chemical composition exists among them resulting in chemical equilibrium, which is upset by the addition of a precipitant with the result that only a partial separation is effected, some of the soluble proteids going into the precipitate, and some of the insoluble proteids remaining in the filtrate. Important contributions to the literature on the hydrolysis of proteids and the cleavage compounds formed have been made by Z. H. Skraup (Monatsh. Chem. 26, 243-264 (I905)), A. Kossel and Dakin (München. Med. Wochnschr. 5 I, 545 (1904)), F. Dubrowin (Inaug. Diss. St. Petersburg, 1902), and Hayashi (Arch. Expt. Path. Pharmakol. 52, 289 (1905)). R. Steinegger (Landw. Jahrb. Schweiz, 19, 512-527 and 528-529 (1905)) has studied the influence of formaldehyde on casein and other proteid bodies. The increased acidity caused by the addition of formaldehyde to milk is explained by the formation of a compound which is free from the amphoteric 
character of the proteid body. The carboxyl groups present, therefore, have their full value and may be titrated. The growing practice of polishing barley and peas has received considerable attention. Forster ( $Z$, offentl. Chem. II, 36 (1905)) shakes the suspected sample with chloroform and examines the sediment microscopically. If talc is found to be present, 5 grams of the sample are ignited and the ash fused with soda and saltpeter. The magnesium is determined in the fused residue and calculated to talc $\left(\mathrm{H}_{2} \mathrm{Mg}_{3} \mathrm{Si}_{4} \mathrm{O}_{12}\right)$. In this way the small amount of magnesium naturally present is also considered to be derived from talc. This slight inaccuracy is avoided by Matthes and Müller $(Z$. offentl. Chem. II, 76 (I905)) who shake 50 grams of the barley with water (using from 500 to $600 \mathrm{cc}$. in all), pour off the supernatant liquid after twenty-four hours, and dry and ignite the residue. The ash is examined microscopically, extracted with hydrochloric acid to remove magnesium that may have come from the outer surface of the barley, and the insoluble portion treated with hydrochloric acid and magnesium determined. Of 53 samples of rice examined by E. v. Rannier (Z. Unters. Nahr.Genuss. 10, 745 (1905)) 40 were coated with talc and 25 were also treated with a blue dye for the purpose of neutralizing the natural yellowish tint of the rice. Hefelmann (Z. offentl. Chem. II, 309) confirms in a general way the results mentioned above. He suggests as provisional maximum limits for talc 0.3 per cent. and 0.2 per cent. for rice and barley, respectively. In several laboratories attention has been given to the study of methods for the determination of glucose and prepared foods. The fermentation methods have been studied by von Raumers ( $Z$. Unters. Nahr.-Genuss. 9, 705 (1905)) who compares the results obtained by fermenting with different varieties of yeasts. He found that compressed yeast is not suitable for this purpose because of the lack of uniformity among different varieties, leading to a corresponding lack of uniformity in the results of different laboratories. He considers that wine and fruit yeasts are not applicable because of their failure to ferment maltose, resulting in too high a figure. Of the yeasts he employed, the bottom fermentation-beer yeastis the only one he regarded as satisfactory for this purpose. This yeast ferments maltose completely, but leaves dextrose unfermented. E. Ewers (Z. offentl. Chem. II, 407 (1905)) recommends the quantitative determination of starch by means of the polariscope after first making the starch soluble by means of acetic acid, dilute hydrochloric acid and hot water. He finds the polarization of wheat, rice and maize starch to be equal, but that of potato starch to be somewhat higher.

Fats and Oils by L. M. Tolman.

Investigations by Winkel (Z. Unters. Nahr.-Genuss, 9, 90-96 (I905)) lead to the conclusion that the changes other than ran- 
cidity which take place in fat exposed to the sunlight are different from those which take place in the dark, but that in both cases the changes are due to chemical action. He also concludes that rancidity in fat is due to micro-organisms. Soltsien (Chem. Rev. Harz. Fettind. I2, I77 (I905)) proposes to detect rancid butter by means of Welman's reagent, which he applies directly to uncolored butter, while with colored butters he first distils with steam and applies the test to the distillate. Klimont (Chem. Rev. Harz. Fettind. 12, I60 (Ig05)) has reviewed the processes taking place when a fat becomes rancid. Petersen (Chem. Ztg. Rep. I8I, I905) has been able to change oleic acid into stearic by means of electrolysis. By dissolving ro grams of oleic acid in I $50 \mathrm{cc}$. of alcohol and adding $3 \mathrm{cc}$. of dilute sulphuric acid (I-4) and using a nickel cathode and a platinum anode in a porcelain cylinder, and passing a current of 1.35 amperes and 20 volts for four hours, the solution being kept at $30-35^{\circ}$, he was able to obtain a heavy precipitate of stearic acid. A number of papers on the unsaturated fatty acids and the addition ( $J$. Moll van Charante: Chem. Centr. I, I309 (1905)) and oxidation products (Alex. Saytzeff: J. Pharm. Chem. 71, 422 (I905)) have been published. Von Molinari and Sonccini (Chem. Ztg. 715 (1905)) have studied the action of ozone on linseed oil and found that one molecule of oleic acid absorbs three molecules of ozone while one molecule of linolic acid absorbs two molecules of ozone. This absorption the authors found to be quantitative and they propose a new number to be used in the analysis of fats to be known as the ozone number. Frank and Kamenetzky (Chem. Centr. I, 696 (1905)), Chem. Ztg. Rep. 75, I905) have prepared some extensive tables of the physical and chemical constants of oils, fats and waxes. New methods for the determination of the phvsical constants of oils and fats have been proposed by Rakusin ( $C$ hem. $Z \operatorname{tg} .84 \mathrm{I}$ (1905)) for the specific gravity and Ubbelohde ( $Z$. angew. Chemie No. 24, 1905) for the melting-point, while Farnsteiner $(Z$. Unters. Nahr.-Genuss. 8, 407 (1905)) has studied the index of refraction and adopts the correction for temperature change of 0.000365 for $\mathrm{I}^{\circ} \mathrm{C}$., the same as adopted by the Association of Official Agricultural Chemists in this country. Deiter (Arb. hyg. chem. Unter. Heft 29 ( 1905 ), in a study of the different methods for the determination of the iodine number of oils, reached the conclusion that the Hanus method was the most satisfactory and that ten to fifteen minutes was a sufficient time for the reaction to take place. The value of an examination of the unsaponifiable matter of fats has been shown by a number of investigations. On account of the effect of the food of the animal on the fat it is often impossible to place any confidence in the color tests, and the determination of the presence of phytosterol is the final test. Olig and Tillmanns (Z. Unters. Nahr.-Genuss. 9, 65 (I905)) have shown, however, that the addition of a slight trace of paraffin 
to the fat under examination made the phytosterol acetate test of Bomer of practically no value as the paraffin reduced the melting-point of the acetate to about $\mathrm{IOO}^{\circ}$, but Polenske ( $A r b$. Kais. Ges. Amt. 22, 557-576) has shown that it is possible to detect this small amount of paraffin by treating the fat with strong sulphuric acid which carbonizes the fat but does not attack the paraffin. Fischer and Peyau (Z. Unters. Nahr.-Genuss. 9, 8I (1905)) found that sulphurous acid would destroy the substance that gives the Halphen reaction in cottonseed oil and that the only way to detect oils treated in this way is by the phytosterol acetate method of Bomer. The Halphen test has been considered a specific test for cottonseed oil but it has been shown that Kapok and Baobab oils give the reaction which in fact seems to be characteristic of the oils of the Malvaceae ( $P$. Soltsien: Chem. Centr. 2, I I33 (1905)). A number of new methods for the detection of coloring-matter in fat have been proposed. Sprinkmeyer and Wagner (Z. Unters. Nahr.-Genuss. 9, 958 (1905)) extract the color from a petroleum ether solution with glacial acetic acid. Arnold (Z. Nahr.-Genuss. ro, 239 (Ig05)) uses an acid alcohol ( $\mathrm{c} \mathrm{cc}$. $\mathrm{HCl}$ to $99 \mathrm{cc}$. of 95 per cent. alcohol). $\mathrm{He}$ takes $5 \mathrm{cc}$. of the melted fat and $2 \mathrm{cc}$. of the alcohol and heats until the solutions mix. The alcohol dissolves the color and collects on the surface of the fat. Fendler (Chem. Rev. Fett. Harzind. I905, 207-237) uses a mixture of nitric acid in ether as a reagent for the determination of added color. Sprinkmeyer and Wagner (Z. Unters. Nahr.-Genuss, Io, 347-353 (I905)) have made a study of sesame oil and give the analyses of a number of oils from different countries. Aparin (Zhur. Russ. Fiz. Khim. Obshch. 36, 581-596 (1904)) has studied the composition of the oil of the strawberry and finds it to be largely linolic and linolenic acids with only a trace of oleic acid.

\section{Dairy Products bi L. M. Tolman.}

There have been several valuable papers on the effect of the food on the composition of milk: One (Morgen C. Berger and G. Fingerling: Landw. Vers. Stat. 62, 25I-386 (I905)) tending to show that where the ration is normal but restricted in quantity the addition of fat and protein to the ration has a favorable effect on the milk production. Fat exerts a specific influence on the production of butter fat while protein shows no such specific action. An addition of carbohydrates to the ration was without influence on either the total yield of milk or the production of butter fat. The conclusion is drawn that food fat is especially suited to the formation of milk fat and that perhaps up to a certain limit cannot be replaced by other food constituents. Other work (T. Pfeiffer, A. Einecke and W. Schneider: Mitt. Landw. Inst. Breslau. 3, 179-225 (1905)), in which such substances such as a mixture of asparagine and cane-sugar were substituted, in quan- 
tities having equal fuel values, for a part of the proteids in a ration rich in proteids, showed no decrease in the quantity of milk but a lowering in the percentages of fat, protein and total solids and a decrease in the actual yield of fat, from which it is concluded that asparagine and the amides in general are not nutrients but sometimes act as stimulants to increase the yield of milk but always at the expense of the other food constituents or the body tissues. Jensen (Landw. Jahrb. Schweiz. 19, 534-559 (1905); Rev. gén. lait. 5, I03-1 10 and $121-128$ (1905); 5, I52I $6 I$, I 78-I85, I98-205 (I906)) calls attention to the fact that with the feeding of large quantities of saltpeter a trace of nitrate is found in the milk; that feeding large quantities of roots increased the amounts of volatile acids in the butter fat, and the feeding of sesame cake increased the content of oleic acid in the milk fat. The general conclusion of all the work is that the composition of the milk and of the milk fat is influenced to a marked degree by the food. Richmond (Analyst, 30, 325-329 (1905)) gives data showing the average composition of 15,9 ro samples of milk. This was as follows: Specific gravity, I.0322; total solids, I2.68 per cent.; fat, 3.75 per cent.; and solids, not fat, 8.94. As an interesting comparison with this are the results on the composition of milk of sheep by Sanna (Staz. sper. agr. ital. 38, 289-306 (1905)) which shows the specific gravity to be I.0385, total solids I 8.34 per cent., fat 7.53 per cent., casein 4.65 per cent., albumin r.or per cent., sugar 4.05 per cent., and ash 0.89 per cent., or solids, not sugar, Io.6o per cent. The question as to the changes that take place in the composition of milk during souring is often of importance to the inspection chemist as the samples are in most cases changed before the analysis is made. In order to test this Thorpe (Analyst 30, 197-205 (1905)), of the government laboratory of England, had i 3 samples of fresh milk kept for periods varying from two to fourteen and one-half weeks and found that the fat content decreased on the average only 0.06 per cent. The loss of solids not fat in the same time was from 0.24 to 0.87 per cent., due mainly to the production of alcohol and volatile acids. These results show that for inspection purposes the analysis of the sour milk is satisfactory in judging the character of the fresh milk. The changes that take place in milk on sterilization and the effect of the sterilization of the milk on digestion, especially of infants, have been the subject of much study, and the results seem to show that the raw milk is more digestible although Brunon (Bull. acad. med. [3] 53, 396-399 (1905)), in his report of the work of the infant milk depot at Rouen which has during the last four and one-half years fed 2,000 infants, 70 per cent. of whom suffered from malnutrition, finds that only a very few of the children failed to do well on sterilized milk. The sterilization was accomplished in an autoclave at $\mathrm{IO}^{\circ} \mathrm{C}$. Jensen and Plattner $(\mathrm{Ann}$. Agr. Suisse, 6, 205-223 (1905) Rev. gén. lait. 4, 361-368, 388-397, 
419-424 (1905)), in an extensive study of the effects of heating milk for various lengths of time and at different temperatures found that marked changes took place in the chemical composition of the milk, and concluded from their work that in order to retain the properties of the raw milk the heating in sterilization should not exceed $70^{\circ} \mathrm{C}$., which is sufficient to destroy pathogenic bacteria.

O. Laxa (Milchwe. Zentbl. I, 538-547 (1905)), in a study of casein and paracasein, finds that lactic acid unites with casein to form lactates and that under the influence of acids paracasein changes to casein. He found that lactates that contained $x$ per cent. or less of lactic acid were insoluble in water while those of higher content were soluble. $\mathrm{He}$ was able to prepare lactates that contained as high as 7.5 per cent. of acid. He concludes that the monolactates and dilactates of Van Slyke and Hart are untenable, a conclusion that these authors have reached in their later work. He explains the curdling of milk by the formation of lactic acid which changes the phosphates of the milk into acid salts and the precipitation of the soluble lactates by the mineral acid. Laquer (Abs. in Osterr. Chem. Ztg. 8, 52 I (I905)) found that paracasein contained more carbon and hydrogen than casein but 0.8 per cent. less nitrogen, that it had the same acidity as casein but was more readily precipitated by salts. Porcher (Compt. rend. I4I, 73-75 and 467-469 (I905)), as the result of his studies on the physiology of the mammary gland, concludes that the transformation of glucose into lactose is a function of this gland. Methods for the estimation of fat in milk have been the subject of a great deal of study during the last year. The Gottlieb-Rose or the Sichler "sin-acid" methods both seem to be very promising. A number of chemists have given the GottliebRose method a thorough trial in comparison with the standard methods and have in all cases found it to give reliable results. Thomsen (Mealkeritid. 18, 356-359 (I905)) showed that it was not necessary to peptonize the milk to obtain complete extraction with the Gottlieb-Rose method while unless this is done with the ordinary method of ether extraction low results are obtained. Burr (Z. Unters. Nahr.-Genuss. ro, 286-290 (1905)) considers that the method is applicable to all dairy products. The results on the "sin-acid" method of Sichler have not been so uniform, some chemists finding it as satisfactory (Lotterhos: Molk. Ztg. 19, 145-I46 (I905)) as the Gerber method and others not entirely satisfactory (M. Klassert:Z.Unters. Nahr.-Genuss. 9, I2-I 5 (I905)). Unfortunately, the reagent used in this test is a secret so that the application and improvement of the method is likely to be slow. The advantage of a method, which does not use an acid to dissolve the proteids of the milk, as is the case in the Gerber and Babcock methods, in the analysis of such products as sweetened condensed milk where the acid chars the cane-sugar so that the 
method is not applicable, can be readily seen. The use of a fine sponge as the absorbent material in milk analysis has been tried by Bellier (Ann. chim. analyt. I0, 268-276 (1905)) with success. The sponge was first extracted with dilute hydrochloric acid, alcohol, ether and water and dried. The weight of the sponge prepared in this way remains practically constant. The milk is transferred to the sponge and dried to constant weight, extracted with ether for the fat, treated with formaldehyde to render the proteids insoluble, this is washed with 50 per cent. alcohol containing 5 per cent. of acetic acid and water to remove the sugar and ash thus giving him a complete analysis of the milk on one sample. Another ingenious method has ( $F$. Bordas and Touplain: Ann. chim. analyt. 10, 267-268 (1905); Rev. soc. sci. hyg. aliment. 2, I63-168 (1905)) been proposed for making an analysis of milk on a single portion; io cc. of milk are added drop by drop to a centrifuge tube containing $25 \mathrm{cc}$. of 65 per cent. alcohol acidified with acetic acid and after standing for a few minutes the tube is whirled. The supernatant liquid is poured off and the sugar determined in it. The residue in the tube is extracted with ether several times, whirling each time to settle the insoluble material and decanting the ether, which is evaporated and weighed. The residue in the tube is dried and weighed as casein. The detection of added water in milk is one of the most important determinations that the chemist has to make in the inspection of milk supplies, and the specific gravity and index of refraction of the milk serum have been found of great value in detecting this form of adulteration. Bialon (Milchw. Zentbl. I, 499-502 (I905)) has shown that the method employed in preparing the serum makes considerable difference in its specific gravity. In one case the serum obtained by spontaneous coagulation had a specific gravity of $\mathrm{I} .0284$, that where acetic acid was used $\mathrm{I} .0266$, and that prepared by rennet I.029I. This he explains by the different amounts of phosphates, lime, and proteids left in solution. The serums prepared by the same method did not give uniform results and better results were obtained by the following formula:

$$
\sigma=\frac{100 s-f}{100-\frac{f}{0.933}}
$$

in which $s$ represents the specific gravity of the milk, $f$ the percentage of fat, and 0.933 the average specific gravity of milk fat. For pure milk $\sigma$ or the specific gravity of the fat-free milk was found to be about I.0323. On the basis of a large number of determinations, the author concludes that a specific gravity of 1.0323 or above calculated by this formula shows that the milk is unadulterated, while a lower figure shows that water has been added. The method is, of course, not applicable to curdled milk.

This difference in the serum would affect the results by the index 
of refraction in the same way. The best method of preparing the serum, according to Henseval and Mullie (Rev. gén. lait. 4, $529-538$ (I905)), is to add I cc. of 20 per cent. acetic acid to 50

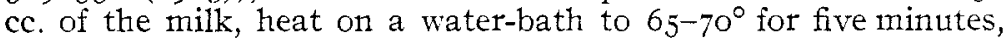
cool to $15^{\circ}$, filter, read the index of refraction at room temperature and calculate to $15^{\circ}$ by the factor 0.000 I 7 for each degree centrigrade. The same result has been attempted by the determination of the freezing-point of the milk and a number of chemists have obtained very uniform figures for this test. Allermann (Landw. Jahr. 19, 499-502 (1905)) found that the average freezingpoint of 23 samples of milk was $-0.571^{\circ} \mathrm{C}$., Barthel (Rev. gén. lait. 4, 505-5I2 (I905)) found it to be very constant between $-0.55^{\circ}$ and $-0.57^{\circ} \mathrm{C}$. Bomstein (Russ. Vrach. 3, 3 (I905)) claims to be able to detect 5 per cent. of added water and Lajoux (Ann. chim. anal. ro, 210-23 I (I905)), from his work, suggests a standard for market milk of $-0.55^{\circ}$ to $0.57^{\circ}$. It must be remembered, however, that such substances as glycerol (Ann. chim. anal. ro, 89-90 (1905)), sodium bicarbonate and formalin influence these results very much. The presence of nitrates in the milk as a test for added water is not always ( $J$. Adorjan: $Z$. landw. Vers. Oestert. 8, 846-85 (1905)) to be relied on as a little dirt in the milk or the water used in washing the cans may cause the milk to give the reaction. The presence of ammonia in milk (Trillat and Sauton: Ann. inst. Pasteur. 19, 494-502 (1905)) is also an indication of added water and may be detected by the nitrogen iodide test as follows: Ten cc. of the milk are placed in a test-tube and treated with Io cc. of a Io per cent. solution of iodine trichloride. The filtrate is carefully neutralized with lime water; when in the presence of ammonia a black precipitate of nitrogen iodide soluble in an excess of the reagent is formed. The value of a preservative which does not change the amount of solids or ash in the milk for preventing changes in milk kept for analysis is evident and some results by Hoft (Chem. Ztg. 29, 54 (I905)) show that formalin to the extent of 4 drops to Ioo cc. does not affect the percentage of solids, but larger amounts cause an appreciable increase. Seligmann (Z. Hyg. Infectionskrank. 49, 325-328 (1905)) proposes the use of Schiff's reagent for the detection of formalin in milk. He adds 2 to 3 drops of sulphuric acid to $5 \mathrm{cc}$. of the milk and then adds the reagent which gives a violet-red color in the presence of as little as r:40,000. Utz (Milchw. Zentbl. I, 175-178 (1905)) detects the presence of hydrogen peroxide in milk by the use of titanic and vanadic acids.

The collection of data as to the variability of the composition of butter fat shows two reports on Holland butter: one, that of Van Sillevoldt (Abs. in Z. Unters, Nahr.-Genuss. 9, 734 (I905)) gives out of 3945 samples examined during January, February and March, only 4 samples that had a Reichert-Meissl number under 24 , while in the three months preceding, 32 samples fell 
below, while Bemelman's report (Contribution à l'étude de la variabilité des constantes des beurres néerlandais. Bréda, I905, pp. 8I ; Abs. in Rev. gén. lait. 4 No. 22, pp. $52 \mathrm{I}-522$ (1905)), on the butter of 485 Holland cows shows that the Reichert-Meissl number quite generally fell below 24 .

The question whether feeding sesame cake to cows will cause the butter to give the Baudoin reaction is of great importance in countries which require that sesame oil shall be added to oleomargarine. Denoel (Bull. Agr. (Brussels) 21, 183-192 (1905)), in some recent experiments, was unable to find a trace of a test in the butter from cows fed on sesame cake. This is contrary to the results of many other experiments, and to what might be expected from the results that have been obtained by feeding cottonseed meal. The detection of cocoanut oil in butter has received a good deal of attention. Jensen (Landw. Jahrb. Schweiz, I9, 477-495 (1905); Ann. Agr. Suisse, 6, 224-246 (1905); Rev. gén. lait. 4, 437-447, 457-464, 48I-490 (1905)) has studied the volatile acids of cocoanut oil and of butter fat and finds that cocoanut oil contains no butyric and very little caproic acid, while butter on the average contains 3.92 per cent. butyric and 1.88 per cent. of caproic acid. Kirshner (Z. Unters. Nahr.-Genuss. 9, 65-70 (1905)) applies this work of Jensen and separates the caprylic acid which is the chief acid of cocoanut oil from the butyric acid by the use of its silver salts.

An interesting paper by Eckles and Rahn (Centr. Bakt. I4, 676-680 (1905)), on the changes taking place in Hartz cheese, shows that of the total nitrogen in the ripe cheese 86.2 per cent. is in the form of albumoses and peptones, 6.7 per cent. exists as amides, 3.5 per cent. as ammonia, and 3.6 per cent. as insoluble proteids, showing a much higher percentage of water-soluble proteids than occurs in Camembert and other kinds of cheese. The changes taking place in Edam cheese in the process of ripening have been studied (F. W. J. Boekhout and J. J. O. de Vries: Centr. Bakt. 2 Abt., 15, $32 \mathrm{I}-334$ (1905)) and the amount of insoluble lime is considered of great importance.

\section{NEW BOOKS.}

General Inorganic Chemistry. By Alexander Smith. New York: The Century Co. 1906 . $x$ viii $+780 \mathrm{pp}$. Price, $\$ 2.25$.

It is a difficult, if not impossible, task to give, within the bounds of a review, an even approximately adequate idea and criticism of this comprehensive and important text on general chemistry.

Professor Smith has succeeded in including in his book, of comparatively small external dimensions, all that is given in the largest college texts on descriptive, inorganic chemistry, and a 